\title{
Agricultural Water Management Problems in Hatay (Turkey)
}

\begin{abstract}
Bekir Demirtaş $^{1 *}$, Erdal Dağıstan ${ }^{1}$, Yalçın Yılmaz ${ }^{2}$, Nuran Tapkı $^{1}$
${ }^{I}$ Department of Agricultural Economics, Faculty of Agriculture, Mustafa Kemal University, 31120 Antakya/Hatay, Turkey ${ }^{2}$ District Governorship, 16800 Orhangazi/Bursa, Turkey A R T I C L E I N F O

\section{Research Article}

Received 17 November 2016 Accepted 14 December 2016

Keywords:

Water management Irrigation unions Farmer satisfaction Binary logistics regression Turkey-Hatay

\section{A B S T R A C T}

This research was completed in 2014, in an attempt to determine the problems and solutions of the irrigation unions and their members who operate in the city of Hatay. The research involves 6 out of 8 irrigation unions located in Hatay. The data was gathered by face to face surveys conducted with 6 union managers and 173 union members. Logistics Regression analysis, which is a multivariate analysis technic was used in the analysis of the variables. It was concluded that $65 \%$ of the producers are satisfied, and $35 \%$ of them are unsatisfied with the irrigation union. The estimate parameters revealed that the irrigation price at low and normal level were the most effective variables. In accordance with the data, evaluated for the managerial staff in the permanent status, showed that the lack of the efficient and subject expert personnel is one of the most important issues directly interfering with the provided service. The delays occurring in the collection of the price of the irrigation water disrupts the maintenance services needed while operating the facilities. The unions need public assistance to cover the personnel expenses, large maintenance processes, and development of the facilities.
\end{abstract}

Corresponding Author:

E-mail: bdemirtas@mku.edu.tr

\section{Introduction}

The total water amount in the world is 1.4 billion cubic kilometers. Approximately $97.5 \%$ is salt water, and approximately $2.5 \%$ is fresh water. $90 \%$ of the fresh water is located in the poles and underground. This situation shows how the easy accessible water is in short supply for the humans (Anonymous, 2011). The water is accepted and evaluated as a natural resource, and generally administered by public institutes. Therefore, water management is centrally planned in the country scale, and practiced in district and basin scale. The related groups using the water (private sector, farmers, fishermen, residents etc.) can get involved to the management process in accordance with the political structure, directly or indirectly (Alpaslan et al., 2008). Water in many developing countries is a great factor that limits the agricultural production, and this is the main income source of the citizens residing in the country side. Therefore, enhancing the agricultural water management can make a major contribution to reduce poverty (Regass et al., 2010). Problems in the irrigation fields are similar to the ones around the world and these include shortage of the water sources, insufficiency in water management, ineffective usage and unbalanced distribution of the water (Oiao et al., 2009). In parallel with the developments throughout the world, the farmer's one-to-one participation was endeavored to the water management, in an effort to enhance the irrigation network operations since 1994. There are four main reasons for the privatization of public irrigation network operators to the private irrigation unions. These reasons are; financially insufficient public, low water price recycle, public request to decrease the expenses and the efforts to increase the self-confidence limits of the farmers (Vermillion, 1995). The purpose of the water management is to provide necessary conditions for efficient water and terrain usage. First condition to provide sustainable irrigated agriculture is to produce efficient and fertile irrigation without harming the environment. Productive benefiting from the irrigation investments can be achieved by efficient and suitable fund of knowledge, effective institutional structure and supervision (Değirmenci, 2008). There were some new problems occurred after the transferring of the agricultural irrigation facilities to the irrigation unions, but generally it is reviewed favorable. These improvements include reduction of the expenses for irrigation and for maintenance of the facilities, and increase of the effectiveness of the operations.

There are 28-million-hectare agricultural land in Turkey, and under today's technical and economic conditions, approximately 8.5 million hectares of this land is available for irrigation (Çakmak et al., 2007). 4.2 million hectares of this available land is irrigated by the public and 1 million hectares is irrigated by the citizens, making it a total of 5.26 million hectare irrigated land. Despite the fact that there are 206.553 (75\%) out of 275.578-hectare irrigation available agricultural land, 
only $144.863(70 \%)$ of this land is actively being irrigated. $32 \%$ of the land opened for irrigation is currently being operated by the public sector and the other $(68 \%)$ is being operated by the private sector.

Hatay province is one of the most southern provinces of Turkey near Syrian borders. Agriculture, tourism, transportation and trade have a significant share in the regional economy. Iron and steel industry in Iskenderun region is also the most important industrial activities. The share of agriculture in the region's GDP is $19 \%$ and its employment share is $29 \%$. Total agricultural land in Hatay is 275500 hectares, $75 \%$ of this land is suitable for irrigation but nowadays 176500 hectares (64\%) of it can be irrigated. While public irrigation land 115.5 thousand hectares (wells, rivers, creeks and streams), 61 thousand hectares that can be irrigated by state investments (irrigation associations, cooperatives and local governments) (ATSO, 2015).

The efficiency for water and irrigation method is highly depended on how successful the cooperation is between the water users and the management (Değirmenci, 2004) The irrigation facilities put into operation by the public in Turkey is being transferred to the irrigation unions, irrigation cooperatives, and local managements such as municipalities and village headman ships (Uçan and Boz 2004). The irrigation unions are a social organization, trying to ensure the convenient usage of the water, in accordance with the targeted goals set out for irrigation systems (Ünal et al., 2004). It is possible to state that, the organizations established by the water users are rather more beneficial than the public utilities. The expected profits from the transferring of the irrigation networks are; the attendance of the farmer and decentralization; reduce of the expenses for the operations and maintenance; equal water distribution; economic usage of the human, time and water resources; selfregulatory with service sufficiency and quality; selfregulatory of the financial resources; directing the resources to the investments; settlement of the disputes between the public and the farmer; quality and economic service; and service equality (Beyribey, 1997). Approximately $70 \%$ of the water in Turkey is consumed for the agricultural land. The importance of the water management is rising in parallel with the high water needs of the industry and service sector in the upcoming years (Çakmak and Aküzüm, 2006). Therefore, it is very important to ensure more efficient water management in the irrigation projects, as well as actualizing the new irrigation projects. Within these scope, a study was conducted to research the management and substructure applications of the 6 active irrigation projects in Hatay, to understand the effects of the satisfaction level of the union members. Furthermore, the solution advises were offered for the encountered problems.

\section{Materials and Methods}

\section{Sampling Method}

The data was gathered by face to face surveys conducted with 8 irrigation unions in Hatay (Table 1).
Two different surveys were conducted to the managers and producers in the research. Within this scope, 173 union member in 31 villages were interviewed face to face by telic sampling method. The members were asked 14 multiple choice questions and the managers were asked 24 multiple choice questions. This data gathered from the irrigation union members in 2014 was used as the research material. The data was evaluated by using the Logistics Regression analysis, which is a multivariate analysis technic.

\section{Analysis and Evaluation Methods}

The data was analyzed by the Logistics Regression model, to evaluate the satisfaction level of the producers from the irrigation union. The Logistics model can be explained as follows: (Hosmer and Lemeshow, 2005; Gujarati, 1999)

$$
P_{i}=E\left(Y=1 \mid X_{i}\right)=\frac{e^{\beta_{0}+\beta_{1} X_{i}}}{1+e^{\beta_{0}+\beta_{1} X_{i}}}=\frac{1}{1+e^{-\left(\beta_{0}+\beta_{1} X_{i}\right)}}
$$

Above the $Y$ is dependent and the $X_{i}{ }^{\prime}$ is independent variables, if the equation would be written simpler as follows:

$$
P_{i}=\frac{1}{1+e^{-Z_{i}}}
$$

Above; that is exactly $=\beta_{0}+\beta_{1} X_{i}$. The possibility of the satisfaction for the producers is $P_{i}$, and the possibility of the dissatisfaction of them is $1-P_{i}$. Therefore;

$\frac{P_{i}}{1-P_{i}}=\frac{1+e^{Z_{i}}}{1+e^{-Z_{i}}}=e^{Z_{i}}$ in this case, $\frac{P_{i}}{1-P_{i}}$ is the odds for the satisfied to be dissatisfied.

The natural logarithm of the above equation will provide the logit model and it will be;

$$
L_{i}=\operatorname{In}\left[\frac{P_{i}}{1-P_{i}}\right]=Z_{i},=\beta_{0}+\beta_{1} X_{i}
$$

Where, $L_{i}$ (Logit) goes from $-\infty$ to $+\infty$. One can add as many regressors as may be dictated by the underlying theories. In the formula, $\beta_{1}$ represents the slope, and the $X_{i}$ represents the independent variables. In the analysis, while considering the satisfaction of the producers with $(Y)$ as a dependent variable, the independent variables predicted to effect this was considered as well which are; having the irrigation water sufficient and on time, evaluating the irrigation water prices, supervising the facilities throughout the irrigation season and the status of the communication with the irrigation union. The instructions for the evaluation of the variables were detailed in Table 2. In the final part of the study, the staff, financials, tools and equipment existence, the status of the kit were examined and some of the possible measurements to increase the service quality level were offered. 
Table1 Member numbers of the irrigation unions and the producer number included in the sampling

\begin{tabular}{l|ccc}
\hline \multicolumn{1}{c|}{ Irrigation union name } & Number of members & Number of samples & Rate $(\%)$ \\
\hline Yayladağ & 300 & 10 & 5.8 \\
Samandağ (left) & 663 & 20 & 11.6 \\
Hassa & 1.368 & 25 & 14.5 \\
Kirikhan & 1.500 & 30 & 17.3 \\
Antakya Yarseli & 2.839 & 35 & 20.2 \\
Samandağ (right) & 6.500 & 53 & 30.6 \\
Total & 13.170 & 173 & 100.0 \\
\hline
\end{tabular}

Table 2 The instructions of the variables used in the analysis and their quantile

\begin{tabular}{|c|c|c|c|}
\hline Variables & Details & Frequency & Rate $(\%)$ \\
\hline \multirow{2}{*}{ Satisfaction over the irrigation union } & Satisfied & 113 & 66.3 \\
\hline & Dissatisfied & 60 & 34.7 \\
\hline \multirow{2}{*}{ Sufficiency of the water } & Yes & 107 & 61.8 \\
\hline & *No & 66 & 38.2 \\
\hline \multirow{2}{*}{ Water distribution on time } & Yes & 117 & 67.6 \\
\hline & *No & 56 & 32.4 \\
\hline \multirow{3}{*}{ Irrigation water price } & Low & 67 & 38.7 \\
\hline & Normal & 30 & 17.4 \\
\hline & *High & 76 & 43.9 \\
\hline \multirow{2}{*}{ Supervision over the irrigation } & Yes & 121 & 69.9 \\
\hline & *No & 52 & 30.1 \\
\hline \multirow{2}{*}{ Communication with the irrigation union } & Good & 126 & 72.8 \\
\hline & *Inadequate & 47 & 27.2 \\
\hline
\end{tabular}

* Reference category.

\section{Results and Discussion}

There was a shortage in the irrigation land, after the transferring of the irrigation facilities' management from the public to the irrigation unions in Hatay province. One of the most important reasons for this is, that the agricultural land has been started to use for different purposes. Cotton, vegetable, fruit, corn and wheat are the main harvests in the research field. However, especially in the dry spelt, the irrigation predominantly takes place in the wheat harvested areas. The irrigation price was determined by the union assemblies in the past. The new regulation transferred this authority to the Council of Ministers. The unions cannot determine a lower price than the one set out by the Council of the Ministers. The producers pay the irrigation fees to the union center near the end of the harvesting period. In case of a delay in these payments, there is a $2.5 \%$ default interest, and if no further payments were made after that, the water cut is being applied slowly, and eventually it is cut completely. Therefore, the products are not completely damaged and the sequestration process is being started in the later phases. The irrigation water price varies very closely per decare in the production period. For example; for cotton the price is $50 \mathrm{TL}$, for corn it is $55 \mathrm{TL}$, and for vegetables, it is $53 \mathrm{TL}$.

The irrigation unions which are examined in the research, have a share of $15 \%$ of irrigation land in the province of Hatay. It is possible for the union managed irrigation land to be increased with the new investments, which are still being made. The management for the irrigation land which is out of the irrigation unions' control, is being carried out by DSI (General Directorate of State Hydraulic Works) and the rest are independent irrigation land.

The Evaluation of the Satisfaction Level over the Irrigation Unions

Sustainability of the irrigation system is highly dependent on the producer satisfaction. One of the ways to ensure this is the farmers' active participation in the water management (Ünal et al., 2004). The satisfaction level of the producers from the irrigation unions under different circumstances is shown in Figure 1, as 65\% satisfied and $35 \%$ dissatisfied. Different independent factors were effective with the decisions of the producers. The factors examined in the study are; having the irrigation water sufficient and on time; irrigation water prices; supervision in the irrigation facilities; and the status of the communication between the producers and the union managers. However, it is a fact that there are some other factors highly effective for the producers' satisfaction. In one of the studies completed in the province of Kayseri, where the satisfaction levels were examined of the irrigation association members over the irrigation unions, showed that $56.3 \%$ of them were very satisfied or satisfied, in parallel to this the other $43.7 \%$ of them were either not satisfied or very dissatisfied. Within the scope of the same project, the producers in the province of Şanlıurfa have a satisfaction level of $33 \%$, 
and dissatisfaction level of $67 \%$ over the irrigation associations (Özçekik et al., 1999). In another study conducted among the Gediz Basin Irrigation Union members, it was found out that $75.6 \%$ of them were satisfied and the $24.4 \%$ of them were dissatisfied with the irrigation associations (Kiymaz, 2006). It is obvious that the satisfaction levels and the results can vary between different studies. The results show that there are a lot of different factors effective over the satisfaction levels. To find out what these factors are and their levels of effectiveness, they must be studied under the multivariate analyses. The union managers must conduct studies over the subjects, where the producers are effected negatively and take precautions to increase the satisfaction levels of the producers as well. It is another fact proven by the studies, that when the offered service is successful, the producer satisfaction levels are also increasing. Before analyzing the independent variables, which are considered as highly effective over the producer satisfaction, the effectiveness level of these variables are detailed with graphics below.

Approximately $89 \%$ of the producers who stated they receive the irrigation water on time $(65 \%)$, and $28 \%$ of the ones who stated otherwise (35\%), mentioned that they are satisfied with the irrigation union (Figure 2). Throughout the region, it is a very important issue to receive the irrigation water sufficient, as well as receiving it on time. Upon examining this situation, the satisfaction level of the producers who stated they receive the irrigation water on time $(62 \%)$ is $81 \%$, and the satisfaction level of the ones who stated they do not receive the irrigation water on time (38\%) is $39 \%$, and the rest of the region stated they are not satisfied at all (Figure 3 ). In general, it was witnessed that there are not many issues in terms of receiving the water on time and sufficient. Moreover, the satisfaction level of the producers over the irrigation union level being over $80 \%$ proves that there are not many problems regarding this issue. However, in accordance with the producers in the region lacking knowledge, experience and the technology needed, it was concluded that in general they are overusing the water with the flooding (wild) method. Furthermore, it is widely known that the producers are inclined to ignore the necessary water amount actually needed for the product they are harvesting. This situation causes the land to become arid and lose productivity in the long term. Above that, throughout the months when the dams have insufficient water, wrong distribution of the water to the producers, low water levels through the summer months, excessive leakage in the water channels are few of the reasons for the delayed and insufficient water distributions.

Within the scope of the study, $39 \%$ of the producers who are a member of the irrigation union stated that the irrigation water price is high, $17 \%$ stated it is normal, and the other $44 \%$ stated it is low. When the alteration of the satisfaction level is examined according to the evaluation of the rates for irrigation water from high to low, it was concluded that the rate increased respectively $40.3 \%$, $66.7 \%$ and $86.8 \%$ (Figure 4 ). The rate of the producers who stated the irrigation water price is low and normal is over $60 \%$, and in general there are not many problems in this case. Before the Irrigation Unions, the producers were having the irrigation service from the public and in general they were not paying for the irrigation water. However, after transferring of the irrigation services of the irrigated agricultural lands to the unions, the irrigation became a paid service. This new situation created an important extra expense for the producers. When the situation is examined in terms of the irrigation unions, the irrigation price covers a large amount of the revenues. Therefore, they are badly effected from the delays of the payments for the water fees. The producers who do not or cannot pay these fees on time, may face some sanctions such as water cuts.

It is widely accepted that if the communication between the irrigation union members and the union management is good, that is reflected positively to the satisfaction level of the producers. Among the producers who stated their communication is good with the union management $(73 \%)$, the satisfaction level is $84 \%$, while it was only $15 \%$ among the producers who stated they are not satisfied (27\%) (Figure 5). It is very important for the union management to ensure that the irrigation system is running properly, and make controls to make sure the producers are treated equally. Among the producers who stated that there is indeed a supervision conducted with such purpose (70\%), the satisfaction level is close to $87 \%$, and among the producers who state that there is no supervision at all $(30 \%)$, the satisfaction level is around $15 \%$ (Figure 6). Other than these factors that have been examined, there are some further negative aspects which are; the producers are not being represented enough; lack of water in the dams and water channels built for the irrigation purposes; lack of experience and indifferences of the irrigation union personnel; and moreover, the region being very close to the border is a problem. Additionally, the disputes between the producers about the water distribution, insufficient water channels, limiting of the water in certain periods, and the usage of pesticide for weeds were reported as problems. Similar studies conducted in the area about the causes of the dissatisfaction over the union management are listed as; inflexible behavior with the water distribution (Ünal et al., 2004); disputes between the producers about the usage of the water; problems caused by the inadequate maintenance on the water channels (K1ymaz, 2006); and the problems caused because of the management of the irrigation union not being neutral. It is clearly seen in the study, that the main source of the problems is directly related with the union management and the substructure of the irrigation system. Every single improvement that can be achieved in these issues will effect the satisfaction level of the producers positively.

The main reason of the irrigation projects' failure to satisfy the expectations is the lack of the implementation of the effective irrigation method rather than the planning, project designing, and the problems during the construction. Therefore, in many countries, the experts, the project managers, national planners and the decision 
makers are currently discussing if they should improve the older irrigation projects with the help of the effective irrigation methods or develop new irrigation projects (Değirmenci, 2008). According to the Irrigation Unions Law, the union assembly is selected from the members of the irrigation unions by elections. In order to provide a democratic structure for the establishment of the union bodies, the producers have to be more effective in the management. Therefore, it will be suitable to restrict the

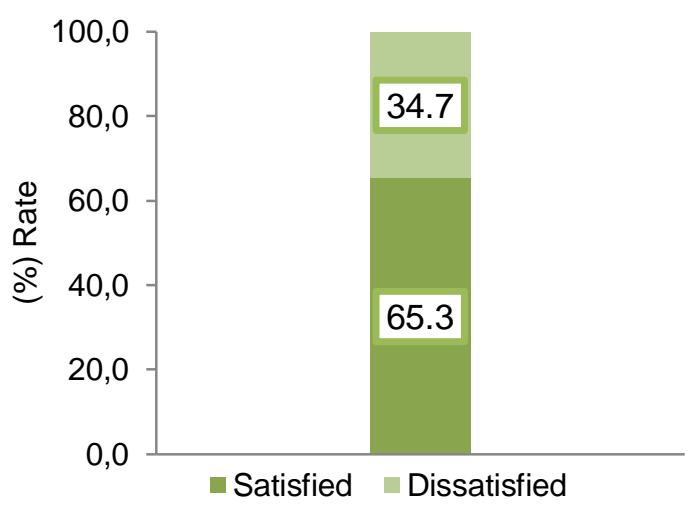

Figure 1 Satisfaction level of the producers over the irrigation union

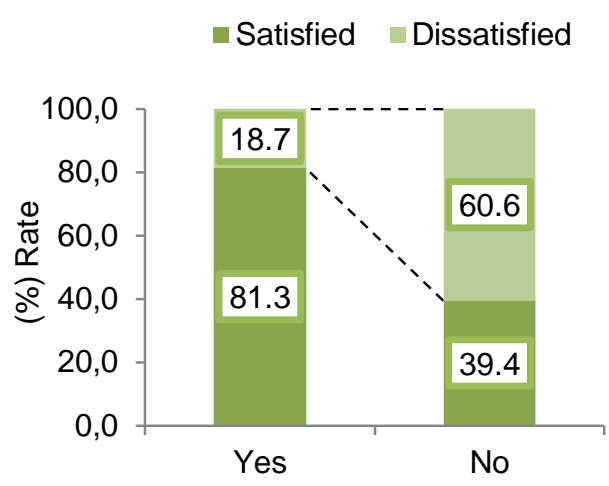

Figure 3 Having sufficient water and satisfaction level

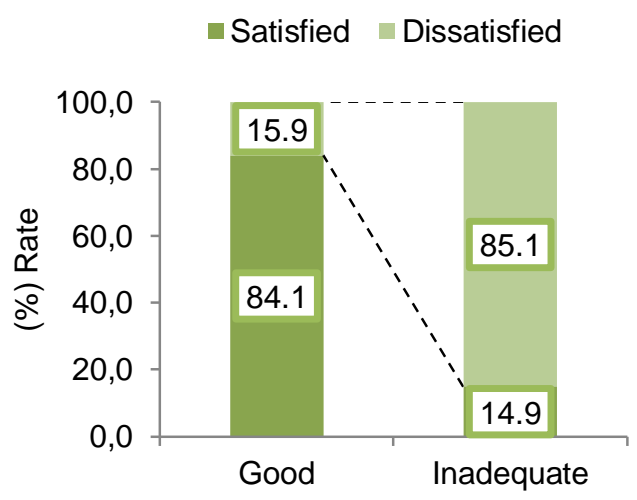

Figure 5 Communication with the union management and satisfaction level authorities of the local managers over the irrigation union. A union management where the irrigation water users are responsible and authorized will be more effective. It was pointed out that the management of the Irrigation Union to be formed by the producers, being the expert of the subject and high education graduate, having good communication skills with the members and attaching importance to the education are few of the most remarkable issues.

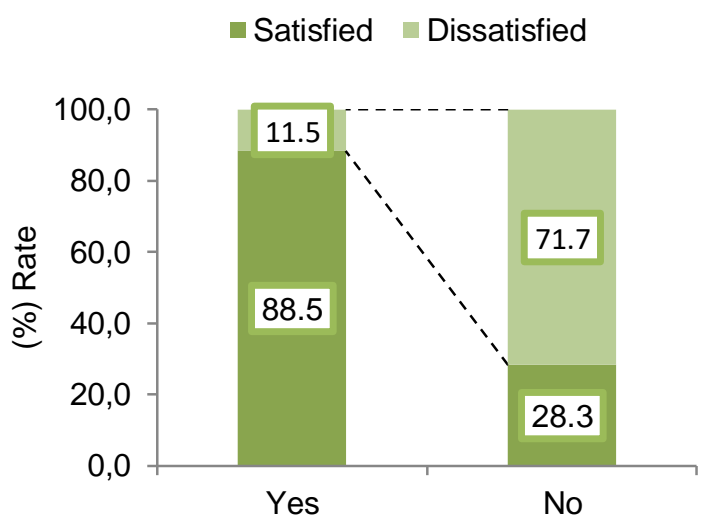

Figure 2 Having the irrigation water on time and satisfaction level

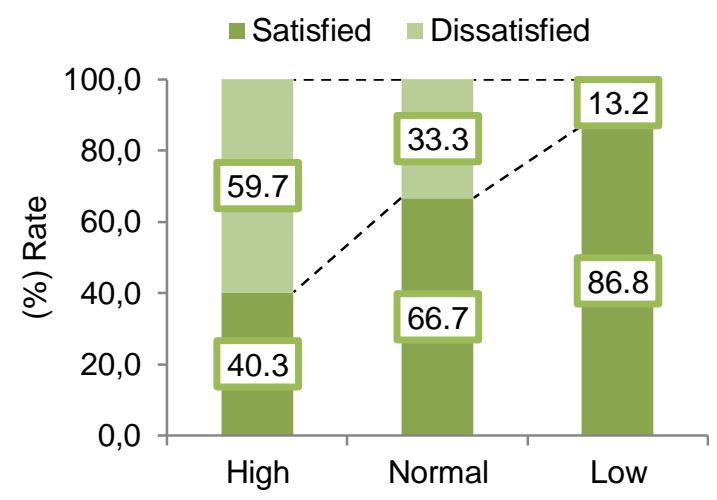

Figure 4 Irrigation water price and satisfaction level

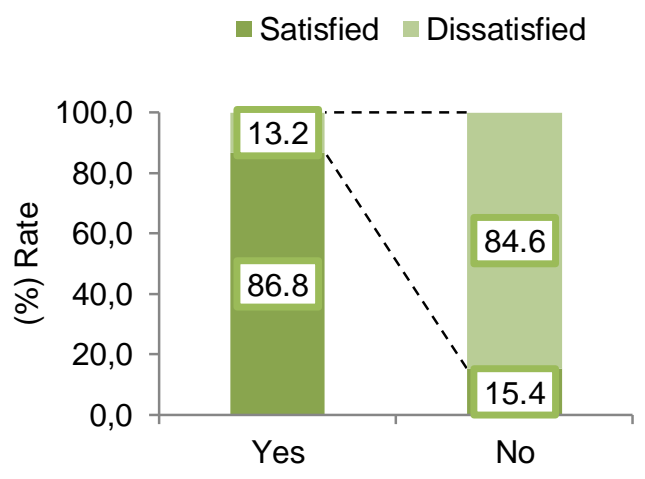

Figure 6 Irrigation network control and satisfaction level 
The values remarking the estimation of the parameters and their importance, which were obtained from the results of the multivariate regression analysis with the variables considered in the study is shown in Table 3 . The calculation of the chi-square value in the phase where the variables are not equal in the beginning of the analysis: $X_{\beta_{0}}^{2}=145.265 p \leq 0.05$ since this is important, it was determined that including one or more of the independent variables in the model will help explaining the change for the dependent variable which will occur. Since the constant term which takes place in the beginning model $2 L L$ has a value of 223.328 and the final model reached to $-2 L L$ has a value of 145.265 , the Omnibus Test value calculated in accordance with the model parameters is; (223.328-145.265=78.063) and $\mathrm{P} \leq 0.05$ so the change observed after the estimation of the parameters is significant. Hosmer and Lemeshow test testified that the chi-square fit goodness, evaluates the compatibility of the logistic regression model as a whole (Menard, 2001). Level of this test result is not significant $(\mathrm{P}>0.05)$, indicating that the model data fit is adequate. In other words, among the observed and predicted values by the model, there is no significant difference; model predictions, it is not different from the observed situation. In our study, Hosmer and Lemeshow test result wasn't significant $(0.546>0.05)$ therefore, the model-data fit was found to be sufficient. Since the values of Cox and Snell and Nagelkerke $R^{2}$ obtained after the estimation of the models is quite higher than the ones observed in the estimation, they can be considered sufficient. The correct classification percentage $(91.3 \%)$ obtained after the estimation of the parameters is quite high as well.

Table 3 The estimation of the parameters of the variables and their importance level

\begin{tabular}{|c|c|c|c|c|c|c|}
\hline Variables & $\beta$ & SE & Wald & df & $\mathrm{P}$ & $\operatorname{Exp}(\beta)$ \\
\hline Irrigation water sufficiency (yes) & -1.221 & 0.638 & 3.663 & 1 & 0.056 & 0.295 \\
\hline Water on time (yes) & -1.385 & 0.655 & 4.476 & 1 & 0.034 & 0.250 \\
\hline Irrıgation water price & & & 13.471 & 2 & 0.001 & \\
\hline Irrigation water price (low) & 2.893 & 0.788 & 13.468 & 1 & 0.000 & 18.042 \\
\hline Irrigation water price (normal) & 1.965 & 0.905 & 4.712 & 1 & 0.030 & 7.137 \\
\hline Supervision of irrigation (yes) & -2.824 & 0.699 & 16.341 & 1 & 0.000 & 0.059 \\
\hline Communication (good) & -2.748 & 0.725 & 14.368 & 1 & 0.000 & 0.064 \\
\hline Constant & 3.019 & 0.853 & 12.527 & 1 & 0.000 & 20.478 \\
\hline$-2 \mathrm{LL}$ & \multicolumn{6}{|c|}{145.265} \\
\hline Cox and Snell $\mathrm{R}^{2}$ & \multicolumn{6}{|c|}{0.57} \\
\hline Nagelkerke $\mathrm{R}^{2}$ & \multicolumn{6}{|c|}{0.78} \\
\hline Correct classification percentage & \multicolumn{6}{|c|}{$\% 91.3$} \\
\hline
\end{tabular}

Analyze method: Enter (Standard).

It was decided insignificant after the estimation of the parameter of the variable for the irrigation water sufficiency (yes). It was estimated as high valued for the betting odds that belongs to the producer statements who finds the irrigation water price low and normal in the estimation variables examined in the analysis. According to these values, the producers are really sensitive over the reference values for the high irrigation water prices and it was observed that in case of some changes over these values, the producer satisfaction level will be effected likewise. The statements of the producers who find the irrigation water price low and normal showed that, in case of a one-unit change, the satisfaction level of the producers will be changing 18 units and 7 units respectively. However, the effects of these parameters because of this change is positive. Among the variables considered in accordance with this change shows that, the most effected variable will be the flexible irrigation water prices. The betting odds obtained with the other estimation of the variables being under 1, and the estimation of the parameters being in negative values show that these variables have negative effect over the satisfaction level of the producers. But the effects of these variables were very small. It can also be seen that other factors which was not considered in this study could be effective over the satisfaction level of the producers. In a study conducted in 2010 in Turkey, about the participant management performance in the Irrigation Union and the satisfaction level of the producers; the union's using of the pumps, any problems with the sustainability, the producers finding the irrigation water prices high, and the croplands being too far to the irrigation channels were some of the dependent variables examined. The result of the logistics estimation showed that, the general independent variables determined for the problems have negative effect over the satisfaction level of from the irrigation union (Uysal and Atış, 2010). The factors that effects the producers point of view, to participate in the decision making process for the irrigation unions were examined in a study conducted in 20103. It was calculated by the producers who were a member of the irrigation union before the transformation, the irrigation time, the amount of the irrigation water and the sustainability of the activities are indeed very important for the participation time, on the other hand it was calculated that the pricing politics effected it negatively and maintained below the importance level. From the other different variables, the studies conducted towards the irrigation time execution, appropriate water amount according to the product, and the sustainability of the water channels effected the management transfer in a good way (Yercan, 2003). 
The transfer of the management of the irrigation management was defined by the transferring of the authority and the responsibilities of the irrigation to be transferred from public institution to the irrigation union. The transfer of the irrigation management was a reform that was strongly supported by the Turkish government. This process was achieved by making the producers understand that they participate more in the management of the irrigation systems. Several positive results were achieved in the process of the irrigation management in Turkey, after the transfer of the irrigation management to users from the public. As a result of the management transfer, the money collected from the irrigation prices were doubled. The maintenance costs for the operations were forwarded from the public to the user, capital and reserves were accumulated for some of the future expenses. The personnel expenses occur in the operations and maintenance were reduced and visible enlargements were observed in the current plans (Yercan et al., 2004). The producers were persuaded to participate in the decision making process after the transferring of the management of the agricultural irrigation facilities in Turkey from public to the irrigation unions which are producer organizations. However, it cannot be stated that all the problems were disappeared with the transfer. Moreover, some new problems appeared surface after the transfer, which have not been recognized before. These problems include substructure issues and lack of the resource like insufficient irrigation facilities and water shortage, as well as the problems surfaced in the managerial mistakes. It was concluded in the many studies conducted, that the satisfaction level of the producer and communication depend on many different factors. It is clearly visible that in terms of the problems composition, not only the extent of the producer, but the extent of the management must be examined as well. Thereby, it is possible to discuss both issues which rise from both sides. If the parties that receives and provides service from the decision and politics makers could be examined together, it will be better in order to give the right decisions through taking the necessary step.

\section{Evaluation of the Irrigation Union Management}

The first issue which must be evaluated in the irrigation union management is the personnel existence. It is important to employ and keep personnel who has experience and worked in the irrigation works for a long time, and who lives in the region where the union operates, every year the activities for the employment is high, since there is new employments, and this situation causes the irrigation services to hinder. Moreover, in order to maintain the operations, maintenance and repair services expected from the irrigation unions, the personnel being the expert and the sustainability of them are vital points. The number of the personnel in the unions, and their quality must be supervised and checked by the authorized upper bodies. Permanent staff shortage, unable to find qualified personnel, unable to allocate sufficient staff seem to be a few of the problems encountered. These problems cause the technical services to hinder which must be accomplished by the irrigation union management and the irrigation networks. It was pointed out that the related upper bodies must provide sufficient staff and experts, and give support to cover the personnel expenses for the irrigation unions.

It was observed that the unions examined can spare resource for the expenses occur in the irrigation channels for maintenance and repair, but is insufficient. Especially in the arid periods, the expenses for the electricity rise but the producer revenue reduces. The high salaries of the personnel in the unions is another reason to cut the resources for the expenses of maintenance and repairs. In the study conducted in the Gediz Basin, it was determined that the irrigation unions that cannot spare enough resources for the maintenance and network expenses have a rate of $86 \%$ (Kiymaz, 2006). Nearly all of the agricultural irrigation networks in Spain are operated by the unions, but the irrigation investments for the irrigation is covered by the producers (Sayın, 1993). Government supports these investments $40 \%$, and the rest is covered by the equity capital off the producers or loans. Similar researches showed that in many countries, the maintenance and repair services accomplished by the producers and it is very difficult in Turkey for the producers to cover these services singlehandedly and it is a fact that they need public support.

The situation over the collection of the irrigation water fees by the irrigation union managers, and the examination processed to determine the problems faced, most of the managers pointed out that there are difficulties in this matter. Since the producers have economic struggles, if the payments are not completed, the sanctions provide no effective results, where the producers are subject to a court order to enforce the payment and the parcels being multipartite are few of the reasons. The seasonal waves occurring in parallel with the delay of the consistency between the supply and demand in agricultural production, negative climate conditions, high agricultural risk and uncertainty, and additionally the sector being open to competitiveness, the producer income does not meet the expectations. The producers who cannot estimate their income are having struggles with their payments. The union management charges penalties for the producers who cannot pay the irrigation water fees on time. Furthermore, the default interest penalty, annotation of the irrigation water debt to the land register records are few results, and in case of a very long delay of the payments the irrigation water is cut, and if still there are no payments, the collection of the amounts will be enforced by court order. Most of the union managers stated that these penalties are intimidating for the collection of the irrigation water fees which were not paid. Protection of the irrigation facilities is another obstacle for the unions. The managers stated that the ownership feeling over the irrigation networks for the producers are not mature enough, and the producers do not spare enough time to focus on the other services apart from receiving the irrigation water such as the protection of the irrigation facilities. Producers' participation over the decisions for irrigation, and water distribution plans, 
and irrigation services will reduce these problems. The tool, utensils and equipment required by the irrigation unions for management, coordination, maintenance and repairs, and communication are visibly insufficient. Furthermore, it was observed that if there is a shortage, DSI (General Directorate of State Hydraulic Works) gives support by providing the tools and equipment to complete the maintenance and repair works, if the expenses are covered. It was also observed that the examined unions use cars for the transportation, provide the office tools partially, and use radio transmitters in site conditions for the communication. It was concluded that the unions need public support on these matters.

It was observed that the education level of the union managers and chiefs examined in the research are low (elementary school). Despite the fact that they are all producers, they lack the experience on the irrigation matters, and in accordance with this, they cannot help the producers for guidance, cooperation, and communication matters. It was understood upon examining the technical staff in terms of education, that most of them $(66,67 \%)$ are agricultural engineers. Employing expert, qualified, and experienced technical staff in the unions will proved better solutions for the problems. It is important for the irrigation unions to be picky when choosing the technical staff. Several seminars are conducted by the related institutions like DSI (General Directorate of State Hydraulic Works) and Provincial Directorate of Agriculture on the irrigation matters for the union managers and workers. However, the managers state that these educations are not sufficient. In a study conducted in Italy to examine the problems of the irrigation unions, it was concluded that in order to cover up the deficiencies, it is very important for the state, irrigation unions, research institutions and universities to cooperate with each other. In the past few years, it was reported that the state provided education programs for the producers, irrigation unions and irrigation technicians in Italy (Hamdy et al., 1997). In a research conducted in Turkey, it was concluded that the education provided for the managers are not sufficient, and the reason for this was pointed out to be the differences on the graduation fields. It was also pointed out that the technical staff working in the unions need to be provided with a real irrigation education in the irrigation centers (K1ymaz, 2006). These problems can be handled by providing irrigation and facility operation education for the managers, irrigation union workers and technical staff, who especially are responsible to operate the facilities,

\section{Conclusion}

The operation of the irrigation union management was transferred to the producer organizations from the public with the new legal regulations. Many of the problems occurred before were solved after the transferring of the irrigation facilities to the producers via the cooperation or unions. However, different problems surfaced which was not observed before as well. These problems are mainly caused because of the irrigation management.
In the research, the data obtained by conducting a survey to the union managers and members in the province of Hatay. It was observed that the satisfaction level is above the average with $65.3 \%$. It was also pointed out that, after the multivariate analysis conducted for the satisfaction level of the producers over the irrigation union management, the betting odds and parameter values for the producers who find the irrigation water prices low and normal were found remarkable. The variable for finding the irrigation water sufficient was decided insignificant, and the estimations of the parameters for other variables was decided significant, the betting odds being low, and the parameters being with negative values, their effectiveness was found very low.

The evaluation conducted by obtaining the data from the irrigation union managers, the most important problem with the sustainability of the union operations is about the personnel existence. There are problems with the employment of the staff, especially with permanent status and subject matter experts. Furthermore, the operations are having struggles paying the personnel, maintenance and repair expenses. The delays of the collection of the water fees makes this situation more visible. To maintain the sustainability and improvement of the irrigation unions, public support would be enough in order to provide personnel, financials and tools. Since the education level of the managers of the irrigation unions are low, there are disruptions on the communication, education and guidance matters. Determining an education criterion for the union managers, giving additional authorities for the managers will be good steps taken through the recycling.

\section{References}

Alpaslan N, Tanık A, Dölgen D. 2008. Türkiye'de Su Yönetimi: Sorunlar ve Öneriler. TÜSİAD Yayın No: T/2008-09/469, 216s. İstanbul. Available from: http://tusiad.org/tr/tum/item/3665turkiyede-su-yonetimi---sorunlar-ve-oneriler [Accessed 18.06.2013].

Anonymous. 2011. Dünyada ve Türkiye'de su kaynakları. Available from: http://www.dsi.gov.tr/hizmet/tarim.htm [Accessed 01.08.2013].

ATSO. 2015. Economic report 2015. Antakya Chamber of Commerce and Industry, Available from: http://www.antakyatso.org.tr/index.php?sayfa=economik_report \&dil=eng [Accessed 10.11.2016].

Beyribey M. 1997. Devlet Sulama Şebekelerinde Sistem Performansının Değerlendirilmesi. A.Ü. Ziraat Fakültesi Yayın No: 1480, Bilimsel Araştırmalar ve İncelemeler. 813. Ankara.

Çakmak B, Aküzüm T. 2006. Türkiye'de tarımda su yönetimi, sorunları ve çözüm önerileri. Su Politikaları Kongresi, Ankara, 21-23 Mart, TMMOB, 349-359.

Çakmak B, Kendirli B, Uçar Y. 2007. Evaluation of agricultural water use: A case study for Kizılırmak. Namik Kemal Üniversitesi Tekirdağ Ziraat Fakültesi Dergisi. 4 (2) 175-185. Available from: http://dergipark.ulakbim.gov.tr/jotaf/article/ view/5000075154/5000069503 [Accessed 10.09.2013].

Değirmenci H. 2008. Sulama Yönetimi ve Sorunları. II. Su Politikaları Kongresi, Ankara, 20-22 Mart, TMMOB, Cilt 1. Sayfa: 197-204.

Değirmenci H. 2004. Kahramanmaraş Bölgesinde Bazı Sulama Şebekelerinin Karşılaştırma Göstergeleri ile Değerlendirilmesi. KSÜ Fen ve Mühendislik Dergisi 7(1): 104-110. Available from: http://fmd.ksu.edu.tr/sayi/71/71.104-110.pdf [Accessed 
10.08.2013]

Gujarati DN. 1999. Temel Ekonometri. (Çevirenler: Ü. Şenesen, G. G. Şenesen) İstanbul, Literatür Yayıncılı, ISBN: 975-7860-999.

Güvercin Ö, Boz İ. 2003. Üreticilerin Sulu Tarım Konusundaki Deneyimleri ve Sulama Birliklerine Bakış1: Düziçi İlçesi Örneği. KSÜ Fen ve Mühendislik Dergisi, 6(2):80-90. Available from: http://fmd.ksu.edu.tr/sayi/62/62.80-90.pdf [Accessed 05.08.2013].

Hamdy A, Lacirignola C, Trisorio LC. 1997. Participatory irrigation management: gaining benefits and rising problems: Case study of Italy. International Workshop on Participatory Irrigation Management:Second Generations Problems, Cali, Colombia, 915 February, 3-20.

Hosmer DW, Lemeshow S. 2005. Applied Logistic Regression. Second Edition, New York, USA, A Willey-Interscience Publication, ISBN: 978-0-470-58247-3.

Kıymaz S. 2006. Gediz Havzası Örneğinde Sulama Birliklerinin Sorunları ve Çözüm Yolları. Adana, Çukurova Üniversitesi Fen Bilimleri Enstitüsü, pp: 206.

Menard S. 2001. Applied logistic regression analysis. Sage University Papers Series on Quantitative Applications in the Social Sciences, 07-106, Thousand Oaks, CA: Sage, ISBN: 07619-2208-3.

Oiao G, Zhao L, Klein KK. 2009. Water user associations in inner Mongolia: Factors that influence farmers to join. Agricultural Water Management, 96: 822-830. DOI: 10.1016/j.agwat.2008.11.001.

Özçelik A, Tanrıvermiş H, Gündoğmuş E, Turan A. 1999. Türkiye'de sulama işletmeciliğinin geliştirilmesi yönünden şebekelerin birlik ve kooperatiflere devri ile su fiyatlandırma yöntemlerinin iyileştirilmesi olanakları, Ankara, Tarımsal Araştırma Enstitüsü, Yayın No:32, ss: 248.

Regassa EN, Munir AH, Gina EC, Helle MR, Lawrence S, Barbara VK. 2010. Agricultural water management and poverty linkages. Agricultural Water Management, 97: 520-527. DOI: 10.1016/j.agwat.2009.05.007.

Sayın S. 1993. Ülkemizdeki sulama organizasyonu ve su yönetimi sorunlarına çağdaş yaklaşımlar. TZOB, Çiftçi ve Köy Dünyası Dergisi, (100):10-16

Uçan K, Boz İ. 2005. Sulama birlikleri personelinin mesleki açıdan yeterlilikleri: Kahramanmaraş ili örneği. Erzurum, Atatürk Üniversitesi, Ziraat Fakültesi Dergisi, 36(1): 69-75. . Available from: http://e-dergi.atauni.edu.tr/ataunizfd/article/view/ 1025004776 [Accessed 01.10.2013].

Uysal OK, Atis E. 2010. Assessing the performance of participatory irrigation management over time: A case study from Turkey. Agricultural Water Management, 97: 1017-1025. DOI: 10.1016/j.agwat.2010.02.007.

Ünal HB, Avcı M, Aşık Ş, Akkuzu E, Kılıç M, Karataş BS. 2004. Sulama suyu dağıtımına çiftçi tepkileri: Menemen sol sahil sulama sistemi örneği. Ege Üniversitesi Ziraat Fakültesi Dergisi, 41(3): 165-175. .Available from: http://dergipark. ulakbim.gov.tr/egeziraat/article/view/5000154138 [Accessed 01.10.2013].

Vermillion DL. 1995. Irrigation management transfer: towards an integrated management revolution. In Johnson SH,Vermillion DL, Sagardoy JA. (Eds.). Irrigation management transfer: selected papers from the International Conference on Irrigation Management Transfer, Wuhan, China, 20-24 September 1994. Rome, Italy: FAO. pp.17-20. (FAO Water Reports 5).

Yercan M, Dorsan F, Ul MA. 2004. Comparative analysis of performance criteria in irrigation schemes: a case study of Gediz river basin in Turkey. Agricultural Water Management, 66: 259-266. DOI: 10.1016/j.agwat.2003.10.008.

Yercan M. 2003. Management turning-over and participatory management of irrigation schemes: a case study of the Gediz River Basin Turkey. Agricultural Water Management, 62: 205 214. DOI: 10.1016/S0378-3774(03)00051-9. 